\title{
Evaluating water policy options in agriculture \\ A whole-farm study for the Broye river basin (Switzerland)
}

\section{Journal Article}

Author(s):

Lehmann, Niklaus; Finger, Robert (i)

Publication date:

2013-10

Permanent link:

https://doi.org/10.3929/ethz-b-000078026

Rights / license:

In Copyright - Non-Commercial Use Permitted

Originally published in:

Irrigation and Drainage 62(4), https://doi.org/10.1002/ird.1745 


\section{Postprint}

This is the accepted version of a paper published in Water Policy. This paper has been peerreviewed but does not include the final publisher proof-corrections or journal pagination.

\section{Citation for the original published paper:}

Finger, R., Lehmann, N. (2012). Policy reforms to promote efficient and sustainable water use in Swiss agriculture. Water Policy 14(5): 887-901

Access to the published version may require subscription.

N.B. When citing this work, cite the original published paper. 


\title{
Policy reforms to promote efficient and sustainable water use in Swiss agriculture
}

\begin{abstract}
The more sustainable use of scarce water resources is a policy goal in several countries. Along these lines, current discussions on potential policy reforms in Switzerland comprise the subsidization of water saving irrigation technologies. Currently, the share of drip irrigation systems is low at levels of 3\%. In Switzerland, environmental laws specify levels of water flow that must not be undercut. Variable pricing of water, however, is not used yet. We analyze if subsidies on water saving irrigation techniques would be beneficial in this legislative setting. It shows that such subsidies may have crowding out effects because they could provide incentives to switch from non-irrigated crops (e.g. wheat) to the production of crops (e.g. potatoes) that require irrigation. This may result in even higher water withdrawal rates. Such an increased competition on water resources may also result in adverse conditions for farmers. In contrast, our analysis shows that water prices can lead to a sustainable increase in the share of water-saving technologies, a shift from irrigated to non-irrigated crops and therefore to a reduction of overall water use in agriculture. Thus, the introduction of water prices should have absolute priority if agricultural water policies are reformed in Switzerland.
\end{abstract}

Keywords: agricultural water use, drip irrigation, subsidies, water prices, crowding out effects, Switzerland

\section{Introduction and Background}

Water saving irrigation technologies such as drip irrigation increase the water use efficiency and can thus help to use scarce water resources more sustainable. Consequently, water saving technologies can reduce problems of environmental degradation. Due to this fact, policy makers have an obvious incentive to increase the adoption of these technologies. In Europe, several countries introduced agrienvironmental programs that aim to reduce the quantity of water used in agriculture (EC, 2005). These program schemes for instance give incentives for the conversion of arable to grassland or changes in crop types used (EC, 2005). In this article, we specifically focus on the case of Switzerland, where current discussions of potential policy reforms with regard to agri-environmental programs comprise the subsidization of water saving irrigation technologies as a measure to reduce environmental harms from agricultural water use. More specifically, we analyze if this subsidization is necessarily beneficial 
for the environment and farmers. The goal of this paper is twofold: First, it should provide a basis for policy related discussions regarding sustainable use of water in agriculture. To this end, we develop a theoretical argumentation that is the basis for numerical simulations, which are presented in the final part of the paper. Second, the hypotheses developed in this paper should be the basis for empirical analyses in situations where similar subsidies were actually introduced.

Currently, only $5 \%$ of the agricultural land is irrigated in Switzerland. Though not widespread used, irrigation harms, at least locally, the environment (e.g. fish populations) and agricultural water use is in competition with other potential water users (e.g. Mühlberger de Preux, 2008). The latter effects were especially observed during the drought and heat wave of 2003, where low levels of water flow and the (temporarily) widespread use of irrigation caused precarious situations of water bodies (BUWAL et al., 2004). For Switzerland at large, the use of irrigation in agricultural production shows an increasing trend since the last years (Weber and Schild, 2007). Climate change will increase water needs for agricultural production, and may lead to the frequent occurrence of situations where water demand exceeds water supply from natural water bodies (Fuhrer, 2010). Problems of water (over-) use for irrigation are currently particularly observed in Western Switzerland. Besides irrigation of special crops such as vegetables, agricultural water use is in particular necessary in potato production in this region. Potato production is highly profitable compared to other agricultural activities if measured on a profit per hectare basis. However, its widespread applicability is limited because it requires rather high levels of water input. In particular due to quality requirements (if potatoes are sold for consumption use), rainfed potato production is not possible in this region under the present rainfall regimes during the growing season, and irrigation is thus required (Mühlberger de Preux, 2008).

Robra and Mastrullo (2011) conducted a survey with 115 irrigating farmers in the region of the Broye catchment in Western Switzerland. Respondents indicated that $40 \%$ of the irrigated surface and $47 \%$ of the water used are devoted to potato production. $80 \%$ of the water used for irrigation is taken from rivers or creeks, while water use from groundwater or lakes plays only a minor role (Robra and Mastrullo, 2011). Western Switzerland regularly faces water scarcity in mid-summer, i.e. water flows in rivers and creeks fall below the minimum tolerable levels from an environmental perspective (Mühlberger de Preux, 2008). In the Broye catchment, 89\% of the surveyed farmers use sprinkler irrigation - drip irrigation is used only by $5 \%$ of the farmers (Robra and Mastrullo, 2011). In Switzerland at large, the share of drip irrigation systems is even lower at about 3\% (Weber and Schild, 2007).

The water use efficiency (i.e. the ratio between water available to the plant and the total amount of applied water) is $75 \%$ for sprinkler irrigation systems and $90 \%$ for drip irrigation systems (FAO, 1989). 
Obviously, a switch from sprinkler to drip irrigation would relieve the environmental problem and if all farmers would switch from sprinkler to drip irrigation, about $15 \%$ less water would be required in potato production. Even though return flows from water that is applied to the crop, but not utilized by the crop, may return to the water body via surface runoff or deep percolation after specific time periods (cp. Ward and Pulido-Velazquez, 2008), the water saving property of drip irrigation has an important advantage: In specific periods, for instance, summer months where water flow is lowest and water need for irrigation is highest, the lower amount of water withdrawal from a river for irrigation leads, ceteris paribus, to more stable water flows and thus to lower environmental harms.

The main reason for the non-adoption of drip irrigation in Swiss agriculture is the lower profitability compared to sprinkler irrigation. Even though the water consumption and the electricity or diesel costs for pumping (due to a smaller required pressure) are smaller, it cannot outweigh the much higher fixed costs of the drip irrigation system. Spörri (2011) surveyed detailed information on the costs of different irrigation technology options from existing irrigation projects in Western Switzerland: The fixed costs (water extraction and transportation, hose reel, hoses, raingun, etc.) for a sprinkler irrigation system are - on average - about $700 \mathrm{CHF}$ ha $^{-1}$ year $^{-1}$. In contrast, the drip irrigation system is, with fixed costs of above $2000 \mathrm{CHF} \mathrm{ha}^{-1}$ year $^{-1}$, much more expensive (Spörri, 2011). Variable costs for irrigation in Western Switzerland originate only from electricity or diesel costs for pumping because no variable water prices exist. Based on this background, Lehmann et al. (2011) and Spörri (2011) point out large differences in per hectare profits between drip and sprinkler irrigation systems of more than $1000 \mathrm{CHF} \mathrm{ha}^{-1}$ year $^{-1}$. Thus, (slightly) smaller variable costs in drip irrigation systems can - currently - not outweigh the much higher fixed costs because the farmer is not charged for the extraction of water. Note that an empirical application for potato production in Western Switzerland, which includes more detailed descriptions of costs and benefits from specific irrigation systems, is presented in the final part of the paper.

\section{Current Policy and Proposed Reforms}

In Switzerland, agricultural water use is regulated at two different levels: the government sets the framework legislation that is particularly concerned to avoid environmental harms from water withdrawal, while the cantons (i.e. federals states) are responsible for managing and coordinating water use for agricultural and other purposes. The management and coordination role of cantons may be also delegated to the municipalities. Thus, the Swiss government sets environmental limits for 
water use, e.g. defined by a specific water flow that should not be undercut (see BAFU, 2000, for details). Note that these thresholds reflect maximum tolerable states, but environmental harms may also occur before these thresholds are reached. The use of such regulatory policy elements to prevent catastrophic harms of agricultural water use on the environment is an important and recommended way to influence water use from a governmental perspective (cp. Ward, 2007).

Cantons are responsible to award water use licenses to farmers and other water users. Thus, cantons have freedom to set prices for licenses (fixed costs) as well as water prices. The latter, however, is seldom used in Switzerland and variable costs for farmers are mostly only pumping (i.e. electricity or diesel) costs. Cantons are also responsible to ban water use from water bodies if water flow falls below environmental thresholds. Farmers can receive subsidies for their irrigation projects, i.e. up to about $50 \%$ of the costs for infrastructure concerning water extraction and water transportation can be contributed by the government and the canton. Note that infrastructure beyond extraction and transportation of water (e.g. the sprinkler or drip irrigation application system) is not yet subject to subsidies. In this subsidization process, there are no explicit criteria regarding the technology usedhowever, overall economic and environmental sustainability of the irrigation project have to be proven by the applicant (BLW, 2009).

This current policy does not explicitly support the use of drip irrigation. In order to overcome the mismatch between the desired state of drip irrigation adoption and the current situation, the Swiss government aims to introduce additional subsidy payment schemes for resource efficiency (BLW, 2011). In general, these payments should induce a more efficient use of natural resources such as soil and water. Regarding irrigation, these payments would be used to increase the efficacy of the irrigation infrastructure - i.e. to subsidize drip irrigation. In Swiss agricultural policy such environmental direct payments (embedded in an agri-environmental program) are usually available to all farmers without any restriction (e.g. Finger and Lehmann, 2011). Thus, usually no distinction regarding farm and farmers' characteristics is made in the subsidy distribution process. Along these general implementation processes of agri-environmental measures, a subsidy payment for drip irrigation would thus be available for all farmers. An important question during the recent policy elaboration process is if such subsidies are a good solution to overcome environmental problems. 


\section{Evaluation of Recent Policy Proposals}

At first view, subsidies supporting especially drip irrigation seem to be a good instrument to reduce environmental harms from agricultural water use. However, there might be substantial drawbacks of such policy reform that we outline below. It is important to note that the share of potato production in Western Switzerland is currently low, e.g. $6 \%$ and $3 \%$ of the arable land in the cantons Fribourg and Vaud (SBV, 2011). This is also the result of insufficient amounts of rainfall, and the costs necessary to install an irrigation system. Highly subsidized irrigation systems could give incentive to other farmers to actually start with potato production.

The situation is schematically presented in Figure 1. The population of farmers (land) in a specific region is represented as circle. On the x-axis, the decision drip vs. sprinkler irrigation is presented, while the $y$-axis depicts the decision of growing potatoes vs. other (non-irrigated) crops (e.g. wheat). The solid circle shows the current situation: the majority of land is devoted to other crops (Field C), i.e. not to potatoes. Among the potato producers, mainly sprinkler irrigation is used (Field A) and only a small area is devoted to drip irrigation potato production (Field B). Two potential scenarios on the effects of a subsidy are visualized.

First, the dashed circle shows the first scenario where a subsidy leads to a shift from sprinkler to drip irrigation among potato producers (leftward shift on horizontal axis) - however, there is no shift in the vertical axis, which means that the area proportion of potatoes and other crops remains unaffected. This is actually the desired outcome: farmers mainly use drip instead of sprinkler irrigation, but there is no extension of the potato area and, thus, in sum less water is consumed. Note that the changes indicated in Figure 1 reflect strategic adaptation responses, i.e. comprise a period of more than one growing season. The dotted circle shows the second scenario that is represented as well by a sharp reduction of the sprinkler irrigation area and an increase of drip irrigation. However, this scenario implies an increase of the total potato production area at the expense of other (non-irrigated) crops. Thus, the subsidy has a crowding out effect on other, non-irrigated crops. In sum, even more water may be used under this scenario. 


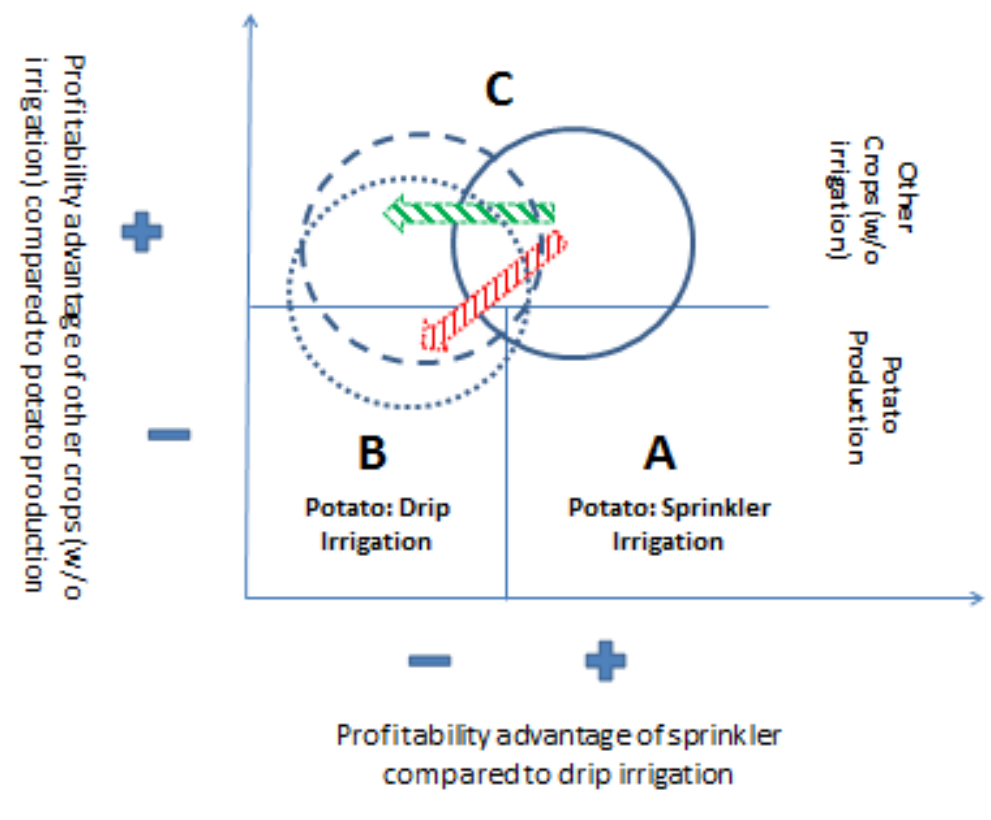

These different responses to subsidies may be the result of heterogeneous starting positions regarding the profitability of different crops (and irrigation techniques) across farmers. Two potential situations are shown in Figure 2:

In Situation 1 (left panel of Figure 2), the potato production with sprinkler irrigation is the most profitable alternative without any subsidies, i.e. in the current situation. If subsidies are paid for drip irrigation, sprinkler irrigation is replaced by drip irrigation as desired.

However, in other situations such subsidy can also have crowding out effects: In Situation 2 (right panel of Figure 2), other (non-irrigated) crops and not potatoes are the most profitable alternative in the current situation without any subsidies. If the level of subsidies is high enough, the non-irrigated crops are replaced by potatoes under drip irrigation. This assumption is in agreement with the study of Ward and Pulido-Velazquez (2008), who have reported a similar observation, i.e. that subsidies for drip irrigation systems even led to an increase of water use on a basin scale.

Situation 2 shows how subsidies for drip irrigation can lead to an increase of the area under potatoes and thus can lead in sum to higher water consumption. This is particularly relevant if it is taken into account that irrigation systems are not a short- but a long-term investment because the amortization period ranges between 10 and 15 years (Spörri, 2011, Finger et al., 2011). If farmers' would - due to high subsidies - adopt drip irrigation, they would be locked in potato production because the irrigation 
infrastructure is present, and not using it would be inefficient. Subsidies thus could have a so called lock-in effect, holding farmers in an irrigation intensive activity.

In reality, situations 1 and 2 are both present because we observe that some farmers use currently irrigated potato production, while other do not cultivate potatoes (and do not use irrigation). Wether a farmer is in either situation depends on natural conditions (e.g. soil quality, slopes) and the costs structure on a specific farm (e.g. for water extraction and transportation).

Figure 2. Potential Effects of Subsidies on the Profitability of Crops and Technologies
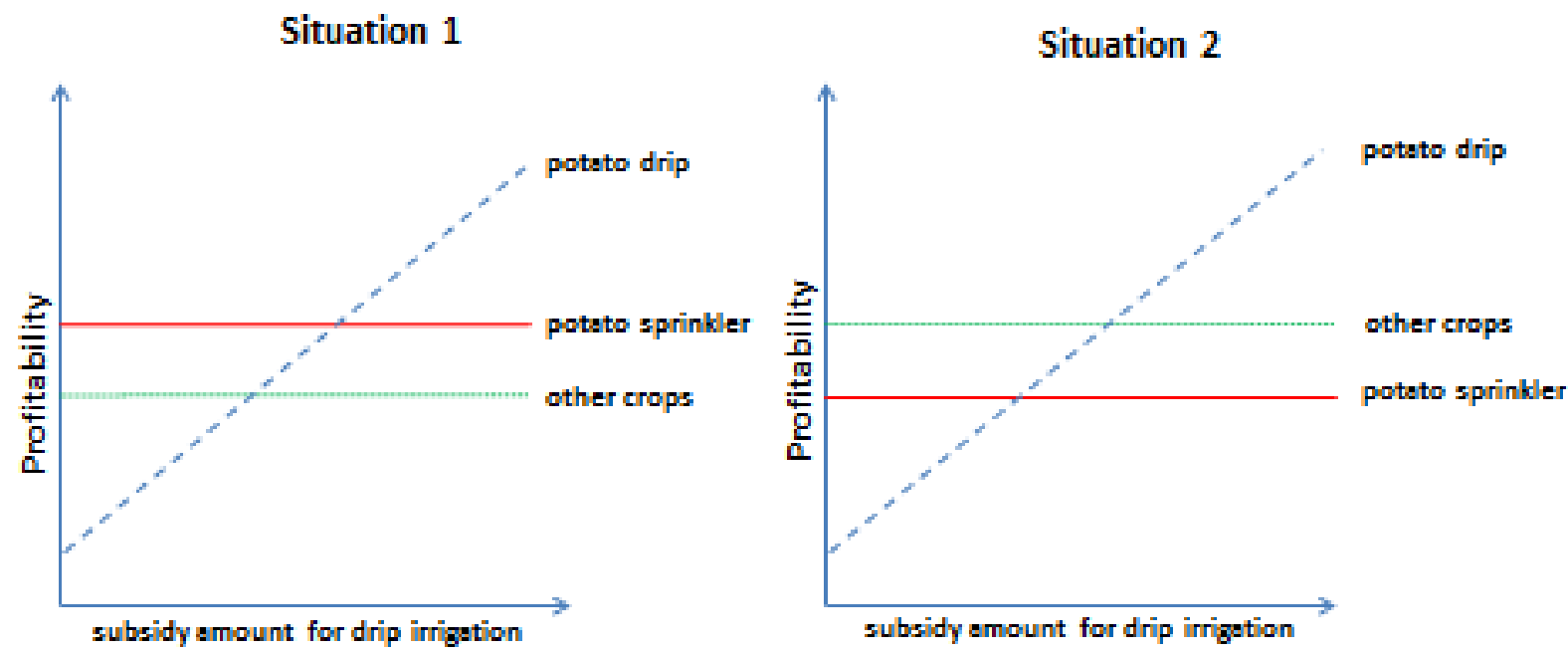

Subsidies for water saving technologies could thus lead to counterintuitive increases of the total water use if the subsidy would crowd out non irrigated crops in favor of potato production. Taking the long service life of irrigation infrastructure into account, this would mean that the water resources could be even more under pressure after the proposed policy reform if more irrigated potato production would take place. From an environmental (here: water saving) perspective, the subsidization of drip irrigation could thus be problematic. 
In addition to the drawback from an environmental perspective, we think that such subsidies could even give the wrong economic incentives to farmers. More specifically, irrigation bans due to low water flows in rivers have become a rather frequent phenomenon in Western Switzerland. Figure 3 shows the periods where water withdrawal has been prohibited in the canton of Vaud from 19982010. The horizontal axis in Figure 3 represents days, while the "yes" or "no" state of water bans is shown on the vertical axis. Thus, the wider the span of an event indicated in Figure 3, the longer was the water ban. Note that in the period of a water ban, all water withdrawal from surface water bodies is prohibited. Figure 3 shows that in 6 out of the last 8 years, water withdrawal was temporarily forbidden. Bans are announced if environmental thresholds of specific river water flow are undercut and are lifted if water flow is above the threshold (see BAFU, 2000, for details). In spring 2011, another ban was issued, which is not shown in Figure 3. If water use is banned frequently, irrigation infrastructure will not pay-off because these bans usually occur if water is actually needed most, i.e. in the hottest and driest years (Lehmann et al., 2011).

Figure 3. Water Withdrawal Bans in the Canton of Vaud 1998-2010.

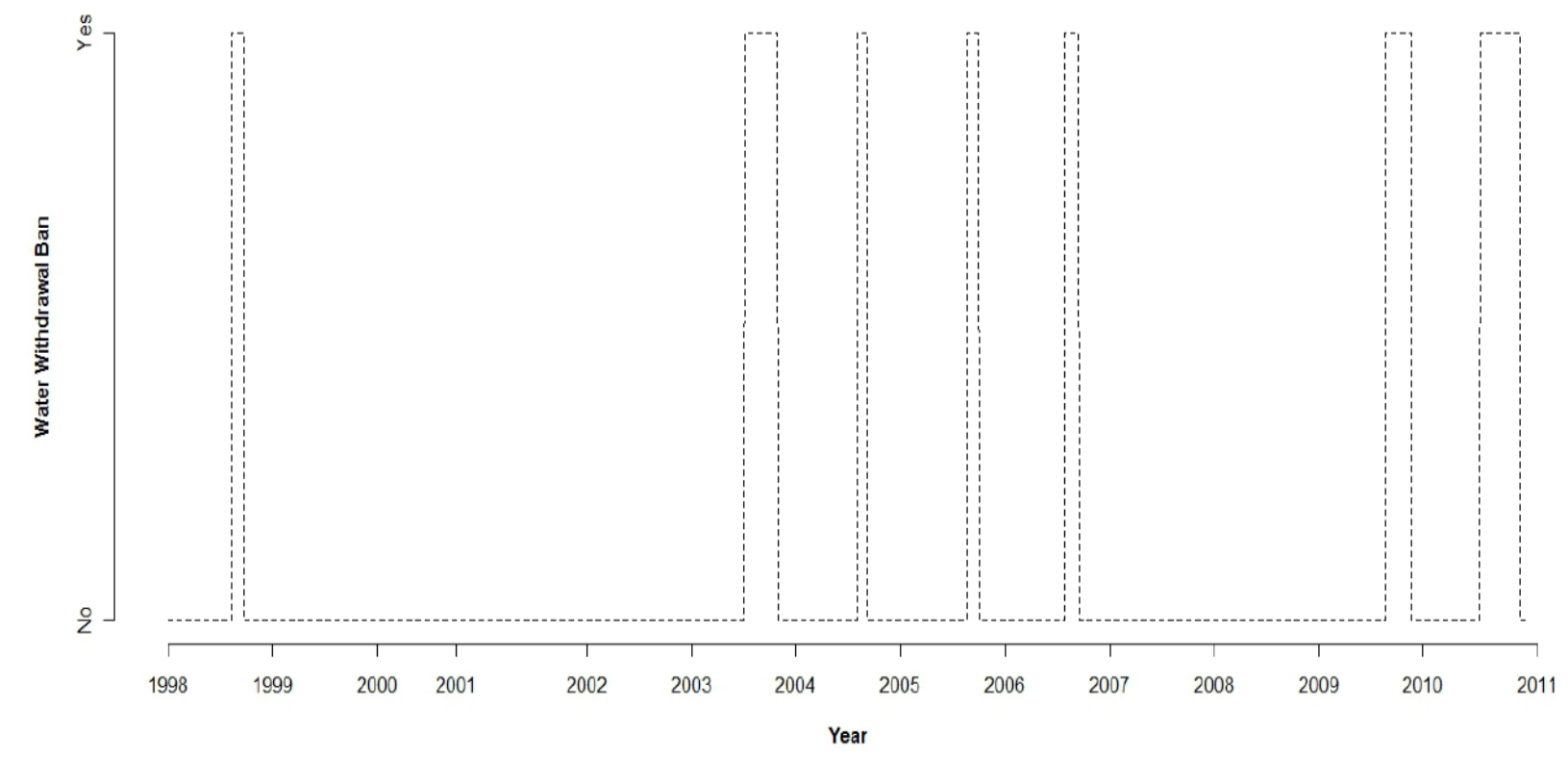

The effect of water bans on the profitability is expected to become even more amplified due to climate change, which will increase the problem of water availability during summer months and thus increase the frequency if water use bans (OCCC, 2007). Thus policy makers have to take expected effects of climate change on water availability in water bodies into account. Furthermore, an increasing agricultural water use due to subsidization as described above may amplify the frequency of bans because environmental thresholds are undercut earlier. Thus, subsidization may imply a higher 
frequency of water bans due to an increased water use, which finally reduces the profitability of the irrigation infrastructure. Thus, the support to environmentally friendly irrigation techniques could result in the paradox situation that a governmentally subsidized irrigation project cannot be used if it is needed most due to governmental water use bans in driest and hottest periods of the growing season.

Alternatively, (more) frequent bans of surface water use farmers may cause an increased use of groundwater, which usually reaches critical levels later than small surface water bodies. If surface water supply is uncertain (or impossible), e.g. in semi-arid and arid regions, it has been particularly observed that farmers switch to groundwater use for irrigation (e.g. Garrido et al., 2006, Rogers et al., 2002). The use of groundwater, however, is even more critically from an environmental and social perspective because groundwater withdrawals often exceeds its re-generation, leading to decreasing water tables, which finally harms other water bodies and other water users (e.g. Garrido et al., 2006). Taking bans of water use as well as potential future developments into account, infrastructure investment due to subsidization can thus cause non-optimally used investments, income losses for farmers, waste tax money and induce more frequent groundwater withdrawal.

In summary, a subsidy for drip irrigation could result in situations where both farmers and the environment are worse-off (lose-lose situation): In periods of water demand peaks, irrigation might be banned frequently - which could result in welfare losses (profit reductions for farmers, wasted tax money) because the irrigation infrastructure cannot be used if it needed most. In periods without irrigation bans, there could be even more water demand due to an increased adoption rate of potato production (with irrigation), leading to even higher pressure on water resources. Anticipatory policy making processes should thus consider other policies to reduce environmental problems of agricultural water use.

\section{Alternative Policy Propositions}

We think that other measures than subsidies for drip irrigation systems could be more efficient, i.e. could induce welfare increases and reduce water use in the water bodies under pressure. One option to avoid the expansion of crops with high water needs at the expense of non-irrigated crops, the subsidy on drip irrigation may be only made available to existing irrigation systems. This would mean that only farmers that switch from their existent sprinkler irrigation system to drip irrigation receive a subsidy. Such policy scheme would give no incentive for an expansion of the irrigated area and thus 
ensure that the total water consumption decreases. However, such policy measure is politically difficult to implement due to the clear inequality across farmers. This is in particular relevant because equity is of highest importance in water management issues, and a fair allocation of resources (and access to technology as well as subsidies) is necessary for a policy change to sustain a political process (Ward, 2007). Along these lines, agricultural policy in Switzerland and other countries is explicitly targeted to reduce inequalities between farmers (e.g. Finger and El Benni, 2011). Furthermore, such a policy would cause inefficient allocation of water and infrastructure resources over time, e.g. if currently non-irrigating farmers would apply for new projects, in situations of farm merger or closing down, etc. Along these lines, an efficient allocation of resources may be difficult.

In contrast to the above presented measures, we think that in particular water prices are an effective instrument to induce drip irrigation adoption, induce a switch from irrigated to non-irrigated crops and thus to reduce the overall amount of water use. We think that the inexistence of water prices is on crucial determinant for the non-adoption of drip irrigation systems, because farmers are given no incentives to save water. Drip irrigation systems have higher water use efficiency than sprinkler irrigation systems, and consequently lower amounts of water have to be used to reach identical crop yields. This water saving property can only give incentives to adopt drip irrigation if water prices are existent (and high enough). Figure 4 visualizes this effect simplified.

Figure 4. Effects of Water Price on the Profitability of Sprinkler and Drip Irrigation.

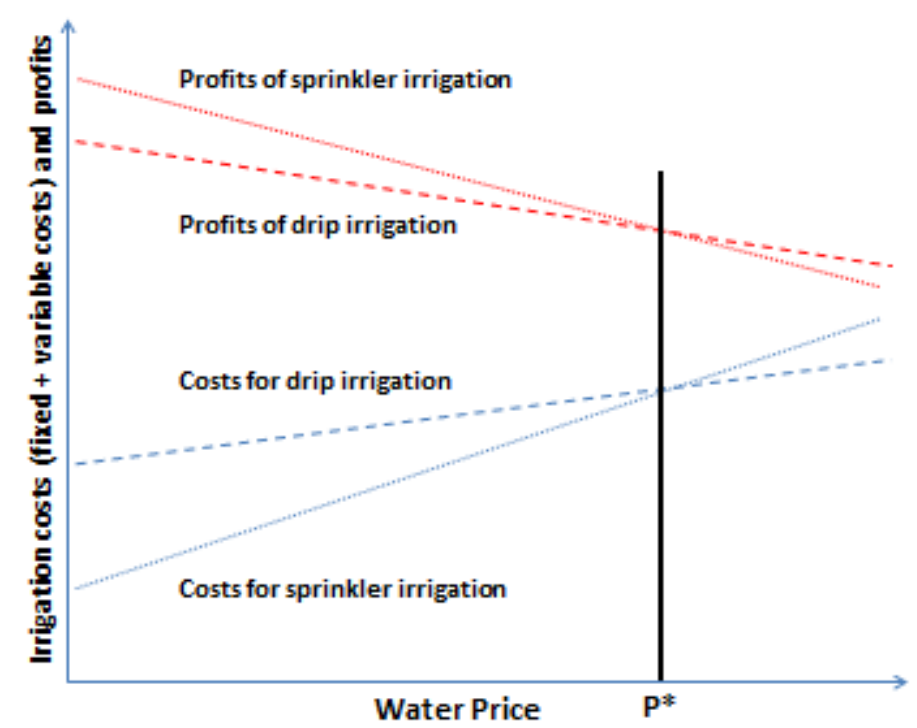


As noted above, a certain amount of water is "saved" if drip irrigation is used instead of sprinkler irrigation, without reductions of crop yields. If the water price is zero, this water saving property of drip irrigation has no monetary value (expect for reduced pumping costs) for the farmer. However, there is an increasing competitive advantage of drip irrigation over sprinkler irrigation if water prices increase, which is shown in Figure 4. If the water price is high enough $\left(\mathrm{P}^{*}\right)$, the water saving property of drip irrigation makes it more profitable than sprinkler irrigation. However, water prices would also make irrigation and thus potato production less attractive for some farmers. Thus, some farmers are expected to switch to drip irrigation, while others switch to crops that require no irrigation. This mechanism is displayed in Figure 5. In total, the area under potatoes decreases, while the majority of the remaining area uses drip irrigation, which in sum reduces the amount of water used for irrigation. Moreover, the smaller area under irrigation is also beneficial from the perspective that accounts for irrigation bans because a reduced agricultural water use may reduce the frequency these bans have to be applied. Thus, future income losses due to irrigation restrictions are avoided.

Figure 5. Effects of Water Price on Land-Use and Irrigation Technology Choice.

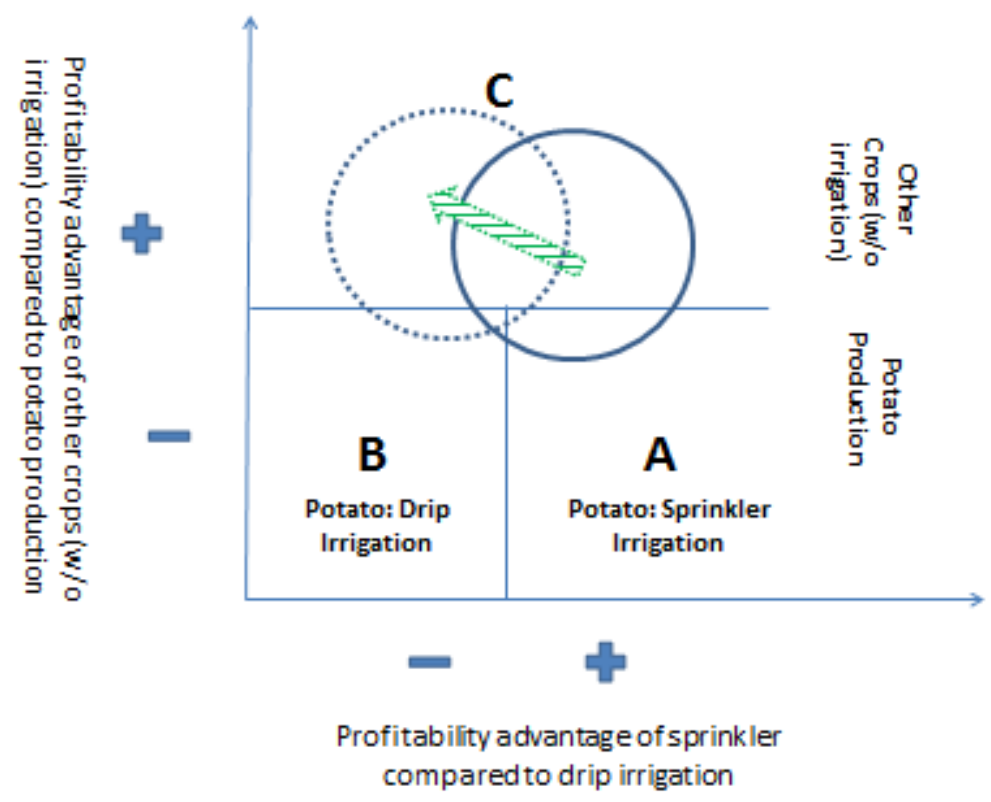

An overview of estimated elasticities of agricultural water demand to water prices is presented by Scheierling et al. (2006), showing that farmers indeed react to price incentives as assumed in our analysis. Furthermore, empirical evidence that water prices have a positive influence on the adoption probabilities of drip irrigation systems are, for instance, provided by Alcon et al. (2011), who provide 
also an overview over related studies. This study also shows that the water price alone is not sufficient as policy instrument. More specifically, education and information are crucial determinants of adoption and have to be explicitly addressed by policy makers to foster a sustainable use of water.

There are obviously also other possible options to reduce water use. These comprise, for instance, the rationing of water, quota systems for water withdrawal and the compulsory use of drip irrigation systems (e.g. Molle et al., 2008). However, a policy goal of 'efficient water use' should be targeted to a situation where only those farmers use irrigation whose costs of water use (taking private, social and environmental costs into account) are lower than the profit he makes from irrigation. A water price that reflects all these costs remains the most efficient tool to reach this goal. However, numerical analyses of the economic and environmental consequences of all possible options should be addressed in future research.

\section{Case Study: Profitability of different irrigation systems in the Broye catchment}

In order to quantitatively compare the financial profitability of sprinkler and drip irrigation systems as well as to show the influence of both water prices and subsidies for drip irrigation systems, we employ a simulation case study in potato production in the Broye catchment located in Western Switzerland (see Lehmann et al., 2011, for an overview). In this region, there exist strong water use conflicts between agriculture and other users (e.g. fishery) as well as environmental goals (Mühlberger de Preux, 2008).

To simulate yields from irrigated potato production under current climatic and soil conditions, we use the process-base crop growth model CropSyst (Stöckle et al., 2003). This model was calibrated for the study region by Klein et al. (2011), based on farm-level observations of potato yields in the period 1981-2009. Note that soil and plant specific characteristics of the region are taken into account in the CropSyst simulations (see Lehmann et al., 2011, for details). CropSyst requires daily weather data as well as information on crop management as input for simulations.

In order to represent current climatic conditions, we use the stochastic weather generator LARS-WG (Semenov and Barrow, 1997; Semenov et al., 1998) that is calibrated on observed weather data for the climate station Payerne (located in the Broye catchment). This weather generator is used to simulate 50 sets of daily weather data that represent current climatic conditions in this region and are 
input for CropSyst simulations. Crop management (e.g. fertilization, sowing) follows the standard recommendations for potato production in Switzerland (e.g. AGRIDEA and FiBL, 2010).

Considering irrigation, we distinguish between sprinkler and drip irrigation. We assume for sprinkler and drip irrigation systems an irrigation efficiency of $75 \%$ and of $90 \%$, respectively, following FAO (1989). Table 1 summarizes the considered revenues and costs in potato production. Furthermore, also information on variable and fixed costs of sprinkler and drip irrigation systems are presented.

Table 1: Revenue and costs in potato production

\begin{tabular}{|c|c|}
\hline \multicolumn{2}{|l|}{$\begin{array}{l}\text { Revenue and Costs (Source: AGRIDEA and FiBL, } \\
\text { 2010) }\end{array}$} \\
\hline $\begin{array}{l}\text { Total potato harvest (mean from } 50 \text { CropSyst } \\
\text { simulations) in } \mathrm{t} \mathrm{ha}^{-1}\end{array}$ & $39.68(S D=4.56)$ \\
\hline $\begin{array}{l}\text { Price for potatoes, first quality ( } 75 \% \text { of total } \\
\text { harvest) }\left(\mathrm{CHF} \mathrm{t}^{-1}\right)\end{array}$ & 460 \\
\hline $\begin{array}{l}\text { Price for potatoes, lower quality ( } 25 \% \text { of total } \\
\text { harvest) }\left(\mathrm{CHF} \mathrm{t}^{-1}\right)\end{array}$ & 100 \\
\hline Direct payment $\left(\mathrm{CHF} \mathrm{ha}^{-1}\right)$ & 1680 \\
\hline $\begin{array}{l}\text { Fixed costs for fertilization and plant protection } \\
(\mathrm{CHF} \mathrm{ha-1)}\end{array}$ & 1337 \\
\hline $\begin{array}{l}\text { Fixed costs for contract work and machinery } \\
\text { costs }\left(\mathrm{CHF} \mathrm{ha}{ }^{-1}\right)\end{array}$ & 1076 \\
\hline $\begin{array}{l}\text { Variable Costs for the Hail insurance (\% of Crop } \\
\text { Yield Revenue) }\end{array}$ & 2.4 \\
\hline Other variable direct costs $\left(\mathrm{CHF} \mathrm{t}^{-1}\right)^{a}$ & 1.35 \\
\hline \multicolumn{2}{|l|}{$\begin{array}{l}\text { Costs for the Irrigation System and Water Use } \\
\text { (Source: Spörri, 2011) }\end{array}$} \\
\hline \multicolumn{2}{|l|}{ Fixed Costs of the Irrigation System* } \\
\hline $\begin{array}{l}\text { Water extraction and transportation system } \\
\text { costs }(\mathrm{CHF} \mathrm{ha-1})\end{array}$ & $\begin{array}{l}\text { Scenario } 1 \text { (very cheap): } 224 \text { (actual costs are 467, but } \\
52 \% \text { are subsidized). Scenario } 2 \text { (very expensive): } 4600\end{array}$ \\
\hline $\begin{array}{l}\text { Option A: Sprinkler irrigation application system } \\
\left(\mathrm{CHF} \mathrm{ha}{ }^{-1}\right)\end{array}$ & 212 \\
\hline $\begin{array}{l}\text { Option B: Drip irrigation application system (CHF } \\
h^{-1} \text { ) }\end{array}$ & $\begin{array}{l}1800 \text { Sensitivity Analyses: } 0 \%, 50 \% \text { and } 100 \% \text { of these } \\
\text { costs are subsidized. }\end{array}$ \\
\hline \multicolumn{2}{|l|}{ Variable Irrigation Costs } \\
\hline 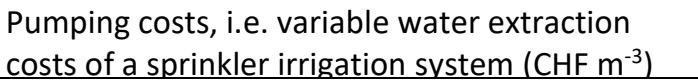 & 0.1 \\
\hline $\begin{array}{l}\text { Pumping costs, i.e. variable water extraction } \\
\text { costs of a drip irrigation system }\left(\mathrm{CHF} \mathrm{m}^{-3}\right)\end{array}$ & 0.05 \\
\hline Water price $\left(\mathrm{CHF} \mathrm{m}^{-3}\right)$ & Is varied from 0 (current situation) to 15 in steps of 0.01 \\
\hline
\end{tabular}

*Asset deprecation periods are assumed to range between 10 and 15 years depending on the type of equipment (cp. Spörri, 2011). SD denotes standard deviation. 
Based on the information shown in Table 1, we compute for each of the 50 weather years the profit margin in potato production assuming different water prices that range from 0 to $15 \mathrm{CHF} \mathrm{m}^{-3}$ (Table 1). The profit margin is defined as follows:

$$
\pi=\rho+D P-c_{f i x}-c_{\text {var }}-c_{i r r i g, f i x}-c_{i r r i g, \text { var }}
$$

Where $\pi$ is the profit margin $(\mathrm{CHF} \mathrm{ha-1}), \rho$ is the revenue $(\mathrm{CHF} \mathrm{ha-1})$ and DP are the governmental direct payments ( CHF ha $\left.{ }^{-1}\right) \cdot c_{f i x}$ stands for the fixed costs $\left(\mathrm{CHF} \mathrm{ha}{ }^{-1}\right), c_{\text {var }}$ for the variable costs, $c_{i r r i g, f i x}$ for the fixed costs of the irrigation system $\left(\mathrm{CHF} \mathrm{ha}{ }^{-1}\right.$ ) and $c_{\text {irrig,var }}$ for the variable irrigation costs ( $\mathrm{CHF}$ $\left.\cdot h a^{-1}\right)$.

Regarding the fixed costs of irrigation, we assume two different values: First, we use average costs that have been reported in existing irrigation projects in the region (following Spörri, 2011). This estimate is biased because it can be assumed that only these irrigation projects are realized that have a positive effect on profits, i.e. those farms that have the lowest costs will establish an irrigation system. However, a large amount of farms does not have an irrigation system and do not produce potatoes. Potentially, this is due to much higher costs for installing an irrigation system. We may assume that one farm is located next to the water body (i.e. has low costs to install water extraction and transportation), while the other is located far away from the water body and thus has very high costs to install water extraction and transportation. These two situations reflect the two possible situations described in Figure 2. They are represented in our numerical analysis using two different assumptions for water extraction and transportation costs (Table 1).

Figure 6 shows the mean value of the profit margin in the 50 simulation years in dependence to the assumed water price, for both sprinkler and drip irrigation systems. Note that Figure 6 represents the situation of farms that use irrigated potato production currently (i.e. Situation 1 in Figure 2). For the drip irrigation system three options are assumed: In the first situation (solid black line), no subsidies for the drip irrigation system are paid (i.e. the current state). In the second (dashed black line) and third (dotted black line) situation $50 \%$ and $100 \%$, respectively, of the drip irrigation application system is subsidized. The red line represents the profitability of the sprinkler irrigation system. Note that in all cases (i.e. also for sprinkler irrigation), a $52 \%$ subsidy on the water extraction and transportation infrastructure are assumed (Table 1).

The solid blue horizontal line represents the profit margin of wheat (following AGRIDEA and FiBL, 2010), which is the most abundant crop in Swiss agriculture and thus chosen as the reference category here. It is produced without irrigation, and thus its profitability does not depend on the water price. 
Figure 6 shows that if the water price is small, irrigated potato production is the most profitable activity. Furthermore, it shows that sprinkler irrigation is more profitable than drip irrigation if the water price is low. More specifically, a water price of about $10 \mathrm{CHF} \mathrm{m}^{-3}$ (point A in Figure 6 ) is required that non-subsidized drip irrigation (black solid line) is more profitable than sprinkler irrigation (red line). At this point, the lower need for water consumption due to higher water efficiency in the drip irrigation system (i.e. the lower variable irrigation costs) outweighs its much higher fixed costs

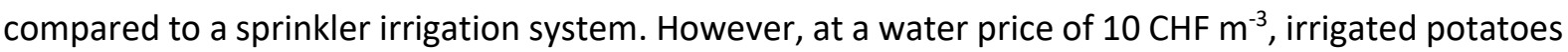
are not profitable anymore (farmers would even make substantial losses) and farmers would grow the here presented alternative wheat, which do not require irrigation (blue solid line). This switch from irrigated potato to non-irrigated wheat production would be already profitable if the water price is larger than $3 \mathrm{CHF} \mathrm{m}^{-3}$ (intersection of red and blue line in Figure 6). Figure 6 also shows that the availability of an alternative that leads to similar high profit margins (e.g. wheat), reduces the potential negative impact of water prices on farmers' profits.

Subsidies for drip irrigation systems lead to a vertical upward shift of the profit margin line (dotted and dashed with solid black line in Figure 6). Consequently, drip irrigation becomes already at a lower water price (of about 3.5 $\mathrm{CHF} \mathrm{m}^{-3}$ ) more profitable than sprinkler irrigation systems (see point $\mathrm{B}$ in Figure 6 ) if $50 \%$ of the fixed costs for the drip irrigation system are subsidized. If all fixed costs of the drip irrigation system are subsidized, sprinkler irrigation is never profitable, but only drip irrigation is employed. 
Figure 6: Profitability of drip and sprinkler irrigation systems vs. the water price. Scenario 1: low fixed costs for water extraction and transport

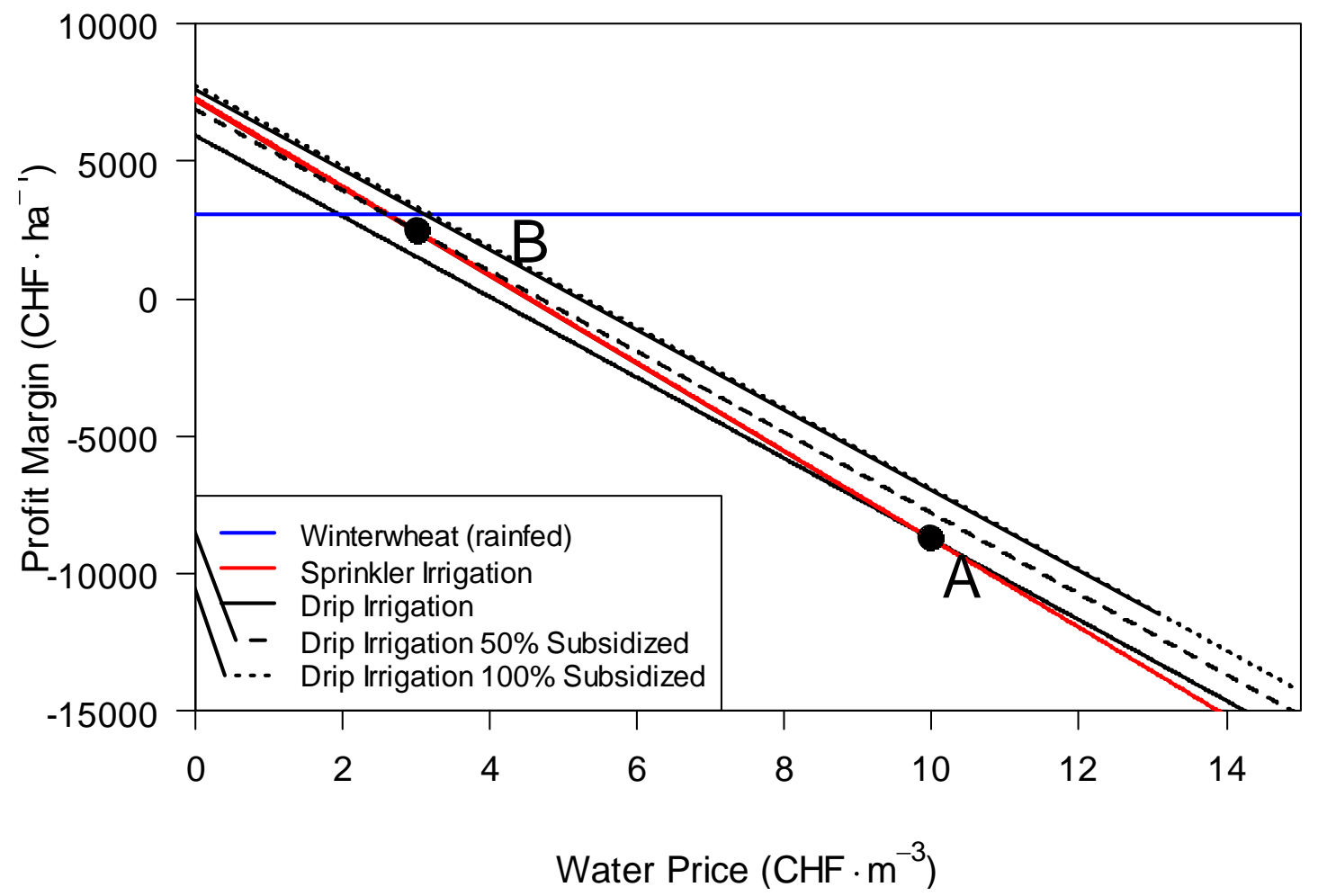

Figure 7 is similar to Figure 6 , but represents the situation of farms that currently do not use irrigated potato production but produce other, non-irrigated crops such as wheat (i.e. Situation 2 in Figure 2). In contrast to the case presented in Figure 6, we assume that the fixed costs for water extraction and transportation are substantially higher, e.g. because the farm is located far away from the water catchment (cp. Table 1).

Figure 7 shows that under current conditions (i.e. no water price, no specific subsidies for drip irrigation systems), wheat is the most profitable alternative and thus no irrigation is used. If water prices increase, this obviously does not affect this choice because no water is used in wheat production. However, Figure 7 shows that if drip irrigation is heavily subsidized (dotted black line), potato production is more profitable. This situation represents the crowding out effect that was discussed in the previous sections. In the displayed situation, however, a small water price (of about $0.5 \mathrm{CHF} \mathrm{m}^{-3}$ ) would be sufficient to make again wheat production more profitable. 
Figure 7: Profitability of drip and sprinkler irrigation systems vs. the water price. Scenario 2: high fixed costs for water extraction and transport

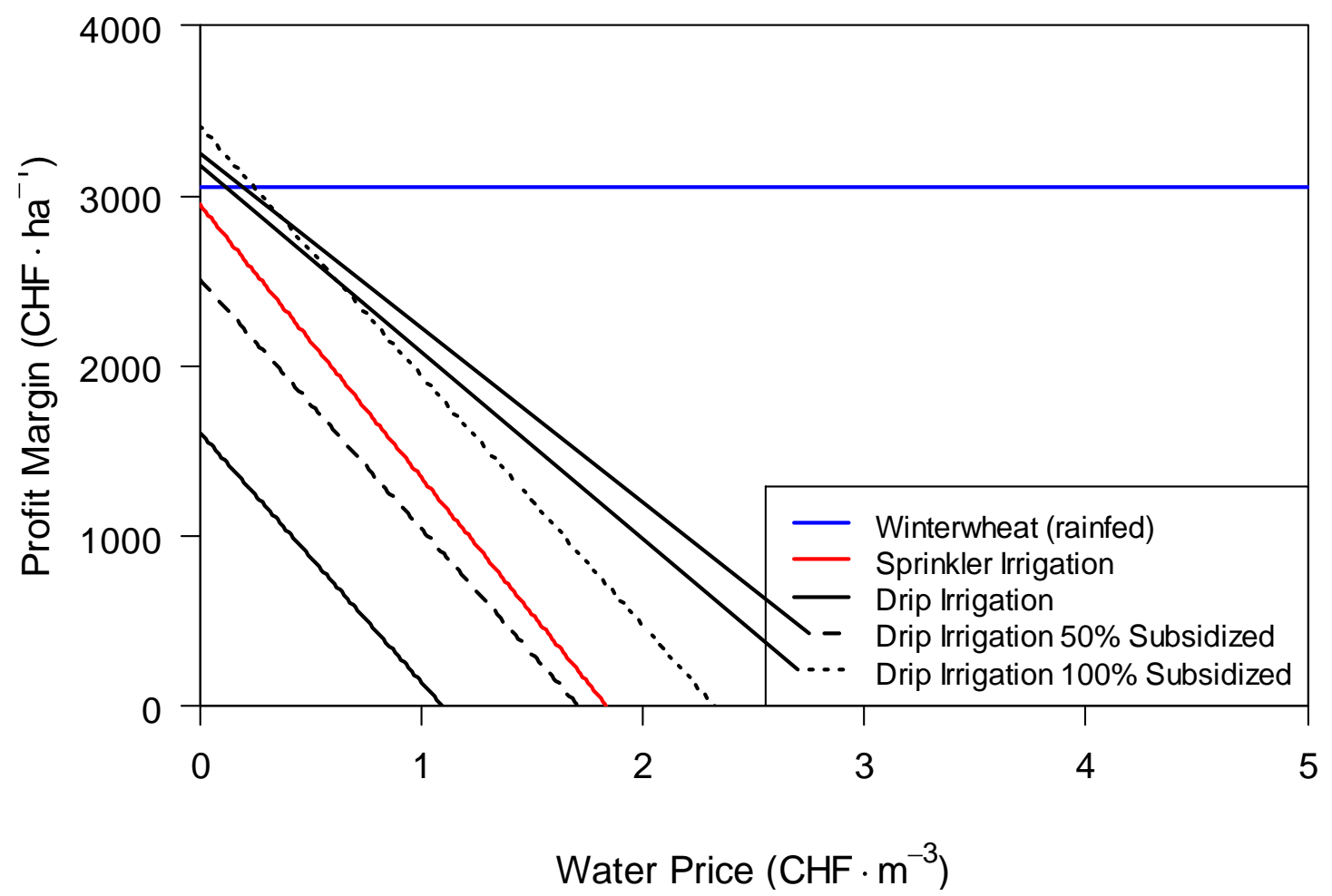

Note that the situations displayed and numbers presented in this section may not be generally applicable for potato production in the Broye catchment or Switzerland at large: each farm (or even each field) faces site-specific environmental characteristics as well as different cost structures, especially with regard to the costs for irrigation infrastructure. Thus, either policy measure will not lead to any corner solution (e.g. no potatoes are produced at all, all farmers switch to drip irrigation), but rather lead to some changes in the percentage of farmers that use specific crops and irrigation techniques as it is indicated in the (theoretically derived) Figures 1 and 5.

Furthermore, the welfare effects of any policy measure (subsidy or water price) remain uncertain. This is due to the fact that both measures create economically inefficient situations, i.e. deadweight losses. A subsidy on drip irrigation will lead to the situation that farmers install such system even though their profit from it is smaller than the full costs of the system. A water price, in contrast, may have the welfare reducing effects of a tax, i.e. the revenue from water prices is smaller than the losses for the farmers. However, the crucial aspect in any welfare assessment on water policy is the value of a more 
sustainable water use in monetary terms. To fill this gap in the situation of Western Switzerland, different valuation methods may be applied to specific stakeholders (e.g. Buchli et al., 2003).

\section{Conclusion and Policy Recommendations}

In conclusion, our analysis shows that subsidies on drip irrigation systems - in absence of water prices - are not the optimal tool to deal with problems of (temporal) water scarcities that have negative environmental effects. It may lead even to an increase of total amounts of water used and may constitute an economic trap for farmers. Thus, subsidies on drip irrigation systems may not necessarily save water at a basin scale (Ward and Pulido-Velazquez, 2008).

In contrast, water prices would lead to increasing adoption rates of drip irrigation and thus contribute to a decreasing total amount of water used. Moreover, our numerical analysis for irrigated potato production in Western Switzerland showed that higher water prices could also lead to a shift to nonirrigated crops such as wheat. Thus, only those producers continue irrigation where benefits from water use for irrigation is higher than its increasing costs due to water prices. These water prices can (and should) give farmers important signals on private, social and environmental costs of water use. To this end, a water price is usually assumed to be optimal if it contains a full-cost recovery including environmental externalities (Rogers et al., 2002). The optimality of the use of water prices compared to any governmental solution without any price for water use is in line with the vast majority of literature (see e.g. Rogers et al., 2002, Zilberman et al., 2008, Ward, 2007). This means that the introduction of water prices should be have absolute priority to reduce environmental loads from agricultural water use and to increase the overall agricultural water use efficiency. However, such introduction has to be accompanied with education and information on water saving cropping and irrigation systems.

The current policy regulation in Switzerland regarding the definition of environmental limits for water use that should not be undercut is a highly effective way to prevent catastrophic harms of agricultural water use on the environment. Thus, this policy element should be maintained. The use of water prices should be on the top of this policy element. A major drawback of a water price compared to subsidies is that agricultural policy makers and farmers would have problems accepting this measure (Bartolini et al., 2010). Thus, the introduction of a water price can be "politically dangerous" (Ward, 2007) and will generate significant political opposition (Johansson et al., 2002). However, this may be particularly the case if basic human needs or incomes of involved stakeholders are at high risk (cp. Ward, 2007). 
In contrast to farmers in arid or semi-arid regions, farmers in Switzerland will not suffer large income reduction in presence of water prices or even if irrigation is abandoned at all because alternative rainfed crop production is still possible (cp. Figure 6 and 7). This should facilitate the policy process for an introduction of water prices. Following Johansson et al. (2002), the implementation of water pricing often requires appropriate institutions and is not free of costs. Due to the current setting in Switzerland, where cantons already license water use and charge (non-variable) fees, the water pricing can be managed by the existing cantonal bodies. The introduction of water prices will imply particular costs, for instance, to measure physical water use as well as for the monitoring and control of measurement systems. In line with the full-cost recovery pricing recommended in the literature (Rogers et al., 2002, Garrido, 2002), these costs shall be completely borne by the farmer. Note that several ways exist to actually price water (see e.g. Johansson et al., 2002, for an overview), which also affect the implementation costs and should be considered during a policy implementation process.

\section{Acknowledgements}

This work was supported by the Swiss National Science Foundation in the framework of the National Centre of Competence in Research on Climate (NCCR Climate) and the National Research Programme 61. We would like to thank the editor and 3 anonymous reviewers for helpful and constructive comments on an earlier draft of this paper. 


\section{References}

AGRIDEA \& FiBL (2010). Deckungsbeiträge 2010. Swiss Association for the Development of Rural Areas (AGRIDEA) and Research Institute for Organic Agriculture (FiBL), Switzerland.Bartolinia, F., Gallerania, V., Raggib, M. \& Viaggi, D. (2010). Water management and irrigated agriculture in Italy: multicriteria analysis of alternative policy scenarios. Water Policy 12, 135-147.

BAFU (2000). Angemessene Restwassermengen: Wie können sie bestimmt werden? Federal Office fort he Environment (BAFU). Bern, Switzerland.

BLW (2009). Wegleitung Landwirtschaftliche Planung. Federal Office for Agriculture (BLW), Bern, Switzerland.

BLW (2011). Vernehmlassung zur Agrarpolitik 2014-2017. Federal Office for Agriculture (BLW), Bern, Switzerland.

Buchli, L., Filippini, M. \& Banfi, S. (2003). Estimating the benefits of low flow alleviation in rivers: the case of the Ticino River. Applied Economics 35, 585-590.

Buwal, BWG \& Meteoschweiz (2004). Auswirkungen des Hitzesommers 2003 auf die Gewässer. Bundesamt für Umwelt, Wald und Landschaft.Schriftenreihe Umwelt, 369, 1-174.

EC (2005). Agri-environment Measures - Overview on General Principles, Types of Measures, and Application. European Commission (EC), Brussels.

FAO (1989). Irrigation Water Management: Irrigation Scheduling. FAO Irrigation Water Management.Training Manuals.

Finger, R. \& El Benni, N. (2011). Spatial Analysis of Income Inequality in Agriculture. Economics Bulletin 31(3), 2138-2150.

Finger, R. \& Lehmann, B. (2011). Adoption of Agri-environmental Programmes in Swiss Crop Production. EuroChoices. In Press

Finger, R., Hediger, W. \& Schmid, S. (2011). Irrigation as Adaptation Strategy to Climate Change: A Biophysical and Economic Appraisal for Swiss Maize Production. Climatic Change 105(3-4), 509528.

Fuhrer, J. (2010). Abschätzung des Bewässerungsbedarfs in der Schweizer Landwirtschaft. Agroscope Reckenholz-Tänikon Research Station, Zurich, Switzerland.

Garrido A (2002). Transition to full-cost pricing of irrigation water for agriculture in OECD countries. Organisation for Economic Co-operation and Development (OECD), Paris

Garrido, A., Martínez-Santos, P. \& Llamas, M. (2006). Groundwater irrigation and its implications for water policy in semiarid countries: the Spanish experience. Hydrogeology Journal 14(3), 340-349.

Johansson, R.C., Tsur, Y., Roe, T.L., Doukkali, R. \& Dinar, A. (2002). Pricing irrigation water: a review of theory and practice. Water Policy 4, 173-199

Klein, T., Calanca, P. Holzkämper, A., Lehmann, N., Rösch, A. \& Fuhrer J. (2011). An efficient crop model calibration procedure for use with farm accountancy data. submitted.

Lehmann, N., Finger, R. \& Klein, T. (2011). Modeling Complex Crop Management-Plant Interactions in Potato Production under Climate Change. International conference on operations research, ETH Zürich, Switzerland, August 30 to September 2, 2011.

Molle, F., Venot, J.P. \& Hassan, Y. (2008). Irrigation in the Jordan Valley: Are water pricing policies overly optimistic? Agricultural Water Management 95, 427-438.

Mühlberger de Preux, C. (2008). Broye: Fish or Chips? Umwelt 2/08, Dossier 26 (Landwirtschaft).

OcCC (2007). Klimaänderung und die Schweiz 2050. OcCC-Organe consultatif sur les changements climatiques, Bern

Robra, J.P. \& Mastrullo, J. (2011). Evaluation d'irrigation dans la Broye des besoins en eau. Manda Terre Sarl, Yverdon, Switzerland. 
Rogers, P., de Silva, R. \& Bhatia, R. (2002). Water is an economic good: How to use prices to promote equity, efficiency and sustainability. Water Policy 4, 1-17.

SBV (2011). Statistische Erhebungen und Schätzungen über Landwirtschaft und Ernährung. Schweizer Bauernverband (SBV, Swiss Farmers' Union), Brugg, Switzerland.

Scheierling, S.M., Loomis, J.B. \& Young, R.A. (2006). Irrigation water demand: A meta-analysis of price elasticities. Water Resource Research, 42, W01411, doi:10.1029/2005WR004009.

Semenov, M.A. \& Barrow, E.M. (1997). Use of a stochastic weather generator in the development of climate change scenarios. Climatic Change 35, 397-414.

Semenov, M.A., Brooks, R.J., Barrow, E.M. \& Richardson, C.W. (1998). Comparison of the WGEN and LARS-WG stochastic weather generators for diverse climates. Climate Research. 10, 95-107.

Spörri, M. (2011). Economic Efficiency of Irrigation Strategies for arable crops under current and future climate scenarios. Bachelor Thesis, ETH Zürich, Switzerland.

Stöckle, C.O., Donatelli M. \& Nelson, R. (2003). CropSyst, a cropping systems simulation Model. European Journal of Agronomy 18(3-4), 289-307.

Ward, F.A. (2007). Decision support for water policy: a review of economic concepts and tools. Water Policy 9, 1-31

Ward, F.A. \& Pulido-Velazquez, M. (2008). Water conservation in irrigation can increase water use. Proceedings of the National Academy of Sciences 105, 18215-18220

Weber, M. \& Schild, A. (2007). Stand der Bewässerung in der Schweiz - Bericht zur Umfrage 2006. Swiss federal office for agriculture, Bern, Switzerland.

Zilberman, D. Sproul, T., Rajagopal, D. Sexton, S. \& Hellegers, P. (2008). Rising energy prices and the economics of water in agriculture. Water Policy 10 (Supplement 1), 11-21. 